\begin{tabular}{lc}
\hline & ANNALES \\
& UNIVERSITATIS MARIAE CURIE-SKŁODOWSKA \\
LOL. V & LEBLIN - POLONIA \\
\hline
\end{tabular}

ISSN: 2451-0491 • e-ISSN: 2543-9340 - CC-BY 4.0 • DOI: 10.17951/en.2020.5.327-341

\title{
Wartość kompetencji międzykulturowych
}

\section{The Value of Intercultural Competences}

\author{
Ewa Głażewska \\ Uniwersytet Marii Curie-Skłodowskiej w Lublinie. Wydział Humanistyczny \\ pl. Marii Curie-Skłodowskiej 4A, 20-031 Lublin, Polska \\ ewa.glazewska@umcs.pl \\ https://orcid.org/0000-0001-8431-7969
}

\begin{abstract}
The aim of the article is to discuss the importance of intercultural competences in building a pluralistic society, open to cultural diversity. Based on the example and analysis of the new program of English language studies, i.e. Intercultural Communication in Education and the Workplace, which operates at the Faculty of Humanities of Maria Curie-Skłodowska University in Lublin, an attempt was made to identify the aspects and ways in which intercultural competences can be acquired and promoted. However, the author does not analyze intercultural education as such, as this has been the subject of research by many other investigators. In the first section, an attempt was be made to define the concept of intercultural competences taking into account cognitive, emotional and behavioral components. The answer to the question why it is important to acquire competences is discussed in the part where the author examines the factors (imperatives) indicating the indispensability of such competences in the contemporary globalized, spatially compressed and cross-linked world. In the final part of the article, the assumptions of the course and the program of intercultural studies are analyzed with a view of presenting a practical proposal of acquiring intercultural competences in Lublin's international academic environment.
\end{abstract}

Keywords: intercultural competences; cultural diversity; intercultural communication; intercultural studies 


\begin{abstract}
Abstrakt. Celem artykułu jest refleksja nad znaczeniem kompetencji międzykulturowych w budowaniu społeczeństwa pluralistycznego, otwartego na różnorodność kulturową. Na przykładzie analizy nowego programu studiów anglojęzycznych Intercultural Communication in Education and the Workplace, funkcjonującego na Wydziale Humanistycznym Uniwersytetu Marii Curie-Skłodowskiej w Lublinie, podjęto próbę wskazania, w jakich aspektach i w jaki sposób można nabywać i promować kompetencje międzykulturowe. Przedmiotem analiz nie jest natomiast edukacja międzykulturowa jako taka, gdyż była ona przedmiotem rozważań wielu innych badaczy. Na początku podjęto próbę zdefiniowania samego pojęcia kompetencje międzykulturowe przy uwzględnieniu komponentów poznawczych, emocjonalnych i behawioralnych. Odpowiedź na pytanie, dlaczego ważne jest nabywanie kompetencji, znajduje się w części omawiającej czynniki (imperatywy) wskazujące na ich niezbędność we współczesnym zglobalizowanym, skompresowanym przestrzennie i usieciowionym świecie. W końcowej części artykułu zamieszczono analizę założeń kierunku i programu studiów międzykulturowych, będącą próbą przedstawienia praktycznej propozycji nabycia kompetencji międzykulturowych w lubelskim akademickim środowisku międzynarodowym.
\end{abstract}

Słowa kluczowe: kompetencje międzykulturowe; różnorodność kulturowa; komunikacja międzykulturowa; studia międzykulturowe

\title{
WPROWADZENIE
}

Celem artykułu jest wskazanie, jak ważną rolę w tworzeniu społeczeństwa wielokulturowego, otwartego na inność, odgrywają kompetencje międzykulturowe. Zagadnienie to omówiono na przykładzie nowego kierunku studiów Intercultural Communication in Education and the Workplace, który od roku akademickiego 2018/2019 został uruchomiony na Wydziale Humanistycznym Uniwersytetu Marii Curie-Skłodowskiej w Lublinie. Na początku zdefiniowano termin kompetencje międzykulturowe, następnie przeanalizowano imperatywy kompetencji międzykulturowych wskazujące, dlaczego i w jakich aspektach są one szczególnie współcześnie przydatne i wartościowe. W końcowej części omówiono program i założenia przyświecające wspomnianemu kierunkowi studiów anglojęzycznych. Jest to jedna z propozycji praktycznego nabycia kompetencji międzykulturowych podjęta na lubelskiej uczelni. Problematyka kompetencji międzykulturowych nie została jednak zanalizowana w aspekcie edukacji międzykulturowej, ponieważ ten aspekt został już omówiony przez wielu innych autorów (zob. Grzybowski 2008; Lewowicki, Ogrodzka-Mazur i Szczurek-Boruta red. 2000; Lewowicki, Różańska i Klajmon-Lech red. 2012; Majchrzak i Zduniak red. 2013; Myrdzik i Karwatowska red. 2009; Nikitorowicz 1995).

Współczesny świat, będący swoistym arrasem kultur i religii, za sprawą dramatycznego przyspieszenia technologiczno-komunikacyjnego staje się areną pełną wyzwań i niebezpieczeństw związanych z kontaktami międzykulturowymi. Nie możemy jej omijać szerokim łukiem ani udawać, że nie istnieje. Gdyby 
świat był wioską liczącą 1000 osób, w skład jej mieszkańców wchodziłoby: 565 Azjatów, 143 Afrykańczyków, 121 Europejczyków, 86 Latynosów (z Ameryki Środkowej i Południowej), 51 Amerykanów (z Ameryki Północnej), 29 mieszkańców Środkowego Wschodu oraz 5 Australijczyków, mieszkańców Oceanii. Skład religijny natomiast przedstawiałby się następująco: 333 stanowiliby chrześcijanie, 210 - muzułmanie, 133 - hinduiści, 58 - buddyści, 4 - sikhowie, 2 - żydzi, 1 - bahaiści, 118 - ludzie praktykujący inne religie, 141 - ateiści lub niereligijni ${ }^{1}$. Jeśli na to nałożyć inne kategorie różnicujące, jak: język czy języki, którymi się posługują, kolor skóry, pochodzenie etniczne, grupa społeczna, status społeczny itd., to jawi się nam społeczeństwo, w którym kontakty interpersonalne stanowią poważne wyzwanie. Kontakty międzykulturowe stały się naszą codziennością na poziomie kształcenia uniwersyteckiego, dlatego należy się na nie właściwie przygotować. W związku z tym użytecznym czy wręcz koniecznym narzędziem staje się nabywanie kompetencji międzykulturowych.

\section{KOMPETENCJE MIĘDZYKULTUROWE - PRÓBA UPORZĄDKOWANIA TERMINOLOGII}

Teoretycy nauk humanistyczno-społecznych od kilku dekad podejmują wysiłki, aby przeanalizować specyfikę kontaktów międzykulturowych i poprawić skuteczność komunikacji międzykulturowej. W badaniach zmian kulturowych uwzględnia się takie zjawiska, jak: asymilacja, adaptacja kulturowa, akulturacja, procesy migracyjne, szok kulturowy i wiele innych pokrewnych fenomenów. Niezwykle ważnym dla antropologów i kulturoznawców pojęciem, które zasłużenie zrobiło karierę naukową, są kompetencje międzykulturowe.

Kompetencje międzykulturowe nie są uważane za zjawisko naturalne, ponieważ na przestrzeni wieków ludzie woleli raczej kontakty z osobami o podobnym zapleczu kulturowym, które określa się jako etnocentryczne. Jedynie dzięki budzeniu świadomości i zrozumieniu różnic kulturowych, które są wynikiem właściwej edukacji i doświadczenia, ludzie zaczynają postrzegać różnice kulturowe jako pozytywne, interesujące i pożądane (Berg i Paige 2009: 431). Rozwijanie kompetencji międzykulturowych jest niezwykle skomplikowane, zwłaszcza jeśli ktoś pracuje z ludźmi z wielu środowisk kulturowych. Trzeba doświadczyć kultury we wszystkich jej klimatach i kontekstach, aby uzyskać jej głębsze zrozumienie i pełniej wykorzystać możliwości zastosowania nabytych umiejętności i technik (Trimble, Pedersen i Rodela 2009: 501).

\footnotetext{
1 Według danych z 2008 roku (Lustig i Koester 2010: 4).
} 
Stownik języka polskiego PWN jako jedno ze znaczeń terminu kompetencja podaje 'zakres czyjejś wiedzy, umiejętności i doświadczenia' (zob. hasło: Kompetencja). Szczególnie pierwsze dwa elementy tej definicji, czyli wiedza i umiejętności, wchodzą w zakres pojęcia kompetencje międzykulturowe. Kompetencje międzykulturowe ${ }^{2}$ - kluczowy termin w XXI wieku - wymagają właśnie odpowiedniej wiedzy, właściwych motywacji oraz wykwalifikowanych działań, przy czym żaden z wymienionych komponentów z osobna nie wystarczy, aby osiągnąć kompetencje międzykulturowe (Lustig i Koester 2010: 68). Kluczowymi czynnikami rozwoju kompetencji są motywacja i chęć poznawania innych, wypływające z dociekliwości.

Kompetencje te łączą w sobie trzy obszary: poznawczy (wiedza i świadomość), emocjonalny (wrażliwość, empatia) oraz behawioralny (konkretne zachowania, umiejętności). Kompetencje międzykulturowe definiowane są jako ogół wiedzy, postaw i zdolności, dzięki którym można zachowywać się właściwie, spójnie i skutecznie w ramach reguł obowiązujących w danym kontekście kulturowym (di Mauro 2015: 283). Kompetencje międzykulturowe można najlepiej scharakteryzować jako przekształcenie interakcji międzykulturowych w samą kulturę (Spitzberg i Changnon 2009: 19).

Wiedza oznacza informacje, które musimy posiadać na temat ludzi, kontekstu i norm obowiązujących w danej kulturze. Informacje te są konieczne, by właściwie interpretować przekazy. Wiedza o innych kulturach często uświadamia nam cechy naszej własnej, zazwyczaj przezroczystej kultury. Nawiązując do Clyde’a Kluckhohna (2018), należy wskazać, że obce kultury służą jako lustro, w którym przeglądamy się w swej nieskończonej różnorodności ${ }^{3}$. Podobnie stwierdził Ryszard Kapuściński (2007: 27): „Inny to zwierciadło, w którym się przyglądam czy - w którym jestem oglądany, to lustro, które mnie demaskuje i obnaża, czego wolelibyśmy jednak uniknąć”. Motywacje to „szereg emocjonalnych skojarzeń, których ludzie doświadczają, antycypując bądź już komunikując się międzykulturowo" (Lustig i Koester 2010: 70). Mówiąc o motywacjach, ujmuje się również uczucia i intencje. Ostatni z wymienionych elementów to działania - chodzi tu o takie zachowania, które uznaje się za właściwe i efektywne. I choć możemy posiadać właściwe informacje na temat kraju, do którego przybywamy i być właściwie zmotywowani do podejmowania kontaktów międzykulturowych,

2 Terminami pokrewnymi używanymi w języku angielskim są: cultural competence, cultural intelligence, multicultural competence, transcultural competence, cross-cultural effectiveness, international competence, cross-cultural adaptation, intercultural sensitivity i inne.

3 To parafraza słynnego cytatu z książki Kluckhohna (2018: 11): „Anthropology holds up a great mirror to man and lets him look at himself in his infinite variety". 
to może nam brakować konkretnych umiejętności, aby uznać, że mamy wysokie kompetencje międzykulturowe.

Myron W. Lustig i Jolene Koester wymieniają osiem podstawowych umiejętności - narzędzi, przyczyniających się do nabycia kompetencji międzykulturowych (tamże: 72-73). Są to:

1. Okazywanie szacunku innym osobom, zarówno w sposób werbalny (np. używanie zwrotów grzecznościowych, tytułów), jak i niewerbalny (rytuały uprzejmości: ukłony, etykieta niewerbalna).

2. Orientacja na wiedzę - pojęcia, jakich się używa, aby określić samego siebie i świat wokoło. Ludzie demonstrują tu indywidualne, osobiste opinie, a nie stereotypowe wypowiedzi dotyczące całych grup ludzkich. Autorzy podają m.in. następujący przykład - zamiast mówić „Mieszkańcy Nowego Jorku muszą być nienormalni, żeby mieszkać w tym mieście", można powiedzieć „Myślę, że Nowy Jork to bardzo trudne do odwiedzin miejsce, nie chciałabym tu mieszkać" (tamże: 73).

3. Empatia, czyli zdolność do trafnego wczuwania się i rozumienia świata osoby, z którą nawiązujemy interakcję.

4. Zarządzanie interakcjami, czyli umiejętność regulowania konwersacji (np. właściwe reakcje na zachowania partnera interakcji).

5. Zachowania zadaniowe związane z relacjami w ramach grupy zawodowej (np. dotyczące stosowności spotkań towarzyskich będących preludium do "robienia biznesu”).

6. Zachowania związane z relacjami międzyludzkimi, czyli takie, które odnoszą się do harmonijnych relacji interpersonalnych w ramach danej grupy. Mogą mieć one charakter komunikatów werbalnych i niewerbalnych, np. okazujących wsparcie czy solidarność.

7. Tolerancja dla niejednoznaczności, czyli zdolność reagowania na nowe, niepewne i nieprzewidywalne sytuacje, okazanie niewielkiego dyskomfortu z tym związanego, umiejętność szybkiej adaptacji. Traktuje się takie sytuacje jako wyzwanie, a nie z wrogością, złością czy sarkazmem. Jak zauważają Lustig i Koester: „Kompetentni komunikatorzy międzykulturowi są w stanie poradzić sobie ze zdenerwowaniem i frustracją, które towarzyszą nowym lub niepewnym sytuacjom, a także szybko dostosować się do zmieniających się warunków" (tamże: 76).

8. Postawa interakcyjna - zdolność reagowania na innych w relacjonujący, niewartościujący i nieoceniający sposób. Taka postawa jest bliska relatywizmowi kulturowemu. Zdaniem Williama B. Gudykunsta i Younga Y. Kima (2008: 498) „zawieszenie wartościowania czy przyznanie mu statusu tymczasowego, do momentu zebrania wystarczających informacji na 
temat odpowiedniej kultury i próby zrozumienia jej członków, znacznie ułatwia porozumienie i skuteczną komunikację". Komunikacja w skrajnie pozytywnej postaci może mieć wymiar synergii w ramach funkcjonowania w heterogenicznych grupach. Filmowy, futurystyczny przykład takiej interakcji słyszymy w Star Treku: „Z zadowoleniem widzę, że się różnimy. Obyśmy razem stali się czymś więcej niż prostą sumą nas obu"4.

Maura di Mauro (2015: 291) proponuje włączenie do zakresu kompetencji międzykulturowych m.in. takich elementów, jak: wrażliwość na różnorodność, aktywne słuchanie i otwartość na różne perspektywy oraz umiejętność integrowania różnych perspektyw, różnych punktów widzenia i różnych wizji świata, a także wartości i opinii. Do zestawu tego dodaje umiejętność tworzenia alternatywnych narracji, co finalnie ma na celu przeprojektowanie praktyk, procesów i polityk społecznych.

Pojęcie kompetencji międzykulturowych w języku angielskim funkcjonuje zarówno w liczbie pojedynczej (intercultural competence) - częściej, jak i mnogiej (intercultural competences). Jednak w języku polskim, zważywszy na wielość elementów wchodzących w skład owych kompetencji, bardziej zasadne wydaje się użycie liczby mnogiej (zob. przegląd modeli koncepcji międzykulturowych w: Bem 2013: 119-136; Chutnik 2007, szczególnie rozdział 5; Grzybowski 2008: 36-39; Spitzberg i Changnon 2009: 2-52).

Jak wskazuje Gert J. Hofstede (2009: 85): „Kompetencje międzykulturowe wymagają umiejętności uczestniczenia w życiu społecznym ludzi, którzy żyją według odmiennych, niepisanych zasad”, często zasad niewerbalnych. Patricia M. King i Marcia Baxter Magolda (2005: 571) zauważają z kolei: „W czasach rosnącej globalnej współzależności tworzenie kompetentnych międzykulturowo obywateli, którzy mogą angażować się w świadome, etyczne podejmowanie decyzji w obliczu problemów, które wiążą się z różnorodnością perspektyw, staje się pilnym priorytetem edukacyjnym". Zdaniem Dereka Boka:

Nigdzie potrzeba ta nie jest odczuwana bardziej intensywnie niż w instytucjach edukacyjnych, które muszą odgrywać główną rolę w przygotowywaniu młodszych pokoleń do życia w kosmopolitycznym świecie, w świecie, w którym muszą współdziałać z obcymi obywatelami i różnymi grupami etnicznymi oraz odczuwać wpływ różnych wartości i kultur na skalę nieporównywalną z poprzednimi pokoleniami. (Bok 2009: 10)

4 Pozdrowienia Wulkana (Star Trek) (zob. Gudykunst i Kim 2008: 496). 
Według Boka wyrobienie „myślenia międzykulturowego” jest dla studentów kluczową potrzebą (zob. Deardorff ed. 2009: 13), ponieważ sama wiedza nie wystarczy. Nabycie takich szerokich kompetencji jest jednak procesem trudnym, trwającym całe życie; nie istnieje żaden punkt szczytowy, w którym ktoś staje się w pełni „kompetentnym międzykulturowo". Co więcej, uczestnictwo w jednym warsztacie bądź kursie może stanowić dobry początek, ale nie jest wystarczające w procesie nabywania kompetencji. Należy raczej uwzględnić wszystkie aspekty kompetencji międzykulturowych w całym procesie kształcenia i rozwoju zawodowego.

Rozważania teoretyczne dotyczące modeli kompetencji międzykulturowych prowadzone są od kilku dekad (zob. przegląd najważniejszych modeli teoretycznych m.in. w: Spitzberg i Changnon 2009: 7-45). Badacze wyróżnili trzy kluczowe komponenty, tj. motywację (uczucia, emocje), wiedzę (poziom kognitywny) oraz umiejętności (poziom behawioralny), kładąc różny nacisk na poszczególne z nich. Podkreślano znaczenie kontekstu, jak również rezultatów (np. efektywność komunikacji, asymilację) (tamże: 2-52), a nabywanie kompetencji traktowano jako określony zbiór elementów, spotkanie interakcyjne bądź proces. Stosunkowo małą uwagę natomiast przywiązywano do takich zmiennych, jak stan psychofizyczny jednostki uczestniczącej w interakcji międzykulturowej, traktując ją jako w pełni racjonalną, podczas gdy interakcje tego typu mogą wywoływać szok kulturowy ze wszystkimi jego konsekwencjami. Na fakt ten zwrócili uwagę Brian H. Spitzberg i Gabrielle Changnon: „[... ] wydaje się, że konceptualizacje kompetencji w zakresie komunikacji międzykulturowej przedstawiały uczestników interakcji jako zbyt abstrakcyjnych, zbyt racjonalnych, zbyt świadomych i zbyt intencjonalnych" (tamże: 35). Zważywszy, że modele kompetencji międzykulturowych powstały głównie w kręgach kulturowych anglojęzycznych, należy odnotować, że mogą cechować się także etnocentryzmem. W związku z tym nasuwa się pytanie, czy modele te znajdują uniwersalne zastosowanie. Aby określić stopień skomplikowania tematyki, warto dodać, że wyróżniono ponad 300 cech i koncepcji powiązanych z kompetencjami międzykulturowymi, np. Jürgen Bolten (2006) posługuje się terminem kompetencja interkulturowa, Milton Bennett z kolei pisze o wrażliwości międzykulturowej, natomiast Darla Deardorff - o kompetencji międzykulturowej (Spitzberg i Changnon 2009: 3643). Analiza poszczególnych modeli jednak nie jest przedmiotem niniejszego artykułu, jest to bowiem materiał na oddzielny tom.

W tym miejscu, aby wykazać powtarzające się u wielu autorów założenia teoretyczne, przywołam jedynie koncepcję Darli Deardorff. Jest to tzw. procesualny model kompetencji międzykulturowych. Proces nabycia kompetencji autorka rozpoczyna od poziomu indywidualnego (postaw, wiedzy i umiejętności), aby 
dojść do poziomu interakcyjnego (wewnętrznych i zewnętrznych rezultatów). Mówiąc o właściwych postawach, ma na myśli szacunek (docenienie innej kultury), otwartość (powstrzymywanie się od ocen) oraz ciekawość i odkrywczość (tolerancja wieloznaczności). Kolejne kluczowe kompetencyjne elementy to: wiedza i zrozumienie (kulturowa samoświadomość, głęboka wiedza o kulturze, świadomość socjolingwistyczna), a także umiejętności, tj. słuchanie, obserwowanie i ocena; analizowanie, interpretowanie i odniesienia. Wskazane elementy prowadzą do pożądanych rezultatów wewnętrznych, takich jak: adaptacyjność, elastyczność, etnorelatywistyczne spojrzenie oraz empatia. Pożądane rezultaty zewnętrzne to skuteczna i właściwa komunikacja oraz zachowanie w sytuacji międzykulturowej. Stopień kompetencji międzykulturowej zależy od nabytych postaw, wiedzy/zrozumienia i umiejętności. Według Deardorff przedstawiony model jest efektem zgody ekspertów co do kluczowych elementów składających się na owe kompetencje oraz potrzeby analizy - jak to ujmuje - „tego mglistego konceptu" (Deardorff 2011: 149; Deardorff i Arasaratnam-Smith eds. 2017); poszczególne jego elementy mogą być rozwijane w odniesieniu do konkretnego kontekstu kulturowego. Rozwój kompetencji międzykulturowych autorka postrzega jako proces ciągły, w ramach którego myślenie krytyczne odgrywa zasadniczą rolę.

\section{DLACZEGO NABYCIE KOMPETENCJI MIĘDZYKULTUROWYCH JEST ISTOTNE?}

Nabycie kompetencji międzykulturowych staje się koniecznością z wielu obiektywnych przyczyn, wśród których wymienić należy kwestie: demograficzne, technologiczne, gospodarcze, pokojowe i interpersonalne (Lustig i Koester 2010: 3).

Imperatyw demograficzny odnosi się do nieuchronnych ruchów migracyjnych. Najlepiej tendencje te pokazuje struktura etniczna Stanów Zjednoczonych. W USA około 18\% ludności we własnym domu używa języka innego niż angielski (tamże: 5). W Polsce zjawiska demograficzne związane z migracjami nie są tak spektakularne, ale np. w obszarze edukacji na poziomie uniwersyteckim Lublin może poszczycić się wysokim odsetkiem umiędzynarodowienia $(6,72 \%)$ - w odniesieniu do studentów pochodzących z Ukrainy UMCS zajmował pierwsze miejsce w Polsce (Skałecka 2010).

Imperatyw technologiczny dotyczy skali i zagęszczenia relacji międzyludzkich odbywających się za sprawą niemal nieograniczonego dostępu do technologii cyfrowych. Komunikacja e-mailowa oraz media społecznościowe nieznające ograniczeń czasu i przestrzeni stanowią najlepsze egzemplifikacje nowoczesnych relacji sieciowych. 
Imperatyw gospodarczy dotyczy przepływów ludzkich w obszarze rynku pracy, który - wyposażony w możliwości, jakich dostarczają nowoczesne technologie - staje się rzeczywiście międzynarodowy i międzykulturowy. Ogólnie szacuje się, że w Polsce zatrudnionych jest w różnych formach od 1,5 mln do 2 mln cudzoziemców, z czego zdecydowana większość to Ukraińcy (Osiecki i Grajewski 2019).

Imperatyw zachowania pokoju wiąże się z najważniejszą wartością łączącą się z nabyciem kompetencji międzykulturowych, tj. postawami i działaniami na rzecz pokojowych relacji międzyludzkich. Imperatyw ten staje się rzeczywiście kluczowy w związku ze wzrostem nastrojów nacjonalistycznych w Polsce, Europie i na świecie, a także z budowaniem polityk opartych na podstawowych antagonistycznych podziałach dychotomicznych na linii swój-obcy oraz narracjach plemiennych prowadzących do megalomanii narodowej ${ }^{5}$. Warto wczytać się w słowa Zygmunta Baumana, który w 2016 roku w eseju zatytułowanym Panika migracyjna i jak się jej (nad)używa, będącym częścią książki Obcy u naszych drzwi, stwierdził:

[...] jedyna droga do rozwiązania obecnej niekomfortowej sytuacji oraz zmierzenia się z przyszłymi wyzwaniami, prowadzi przez odrzucenie zwodniczej pokusy separacji. Zamiast odwracać się od rzeczywistych wyzwań naszych czasów, które stawia przed nami „jedna planeta, jedna ludzkość”, zamiast umywać ręce i odgradzać się od irytujących różnic, niezgodności i narzuconego przez nas samych wyobcowania, musimy szukać okazji do bliskiego, coraz bardziej zażyłego kontaktu, co - miejmy nadzieję - zaowocuje fuzją punktów widzenia, a nie faworyzowanym i planowanym, a przy tym samonapędzającym się rozszczepieniem. (Bauman 2016: 25-26)

Konstatacja Baumana prowadzi nas do ostatniego imperatywu - imperatywu interpersonalnego kompetencji międzykulturowych. Na poziomie relacji interpersonalnych kompetencje ukazują swój najważniejszy wymiar, jako że to nie społeczeństwa czy grupy się komunikują, lecz jednostki, które funkcjonują ramach wielokulturowych rodzin, mają sąsiadów obcokrajowców, studiują z ludźmi pochodzącymi z odmiennych kultur, pracują w firmach zatrudniających obcokrajowców, spędzają wakacje za granicą bądź jedynie czy aż wymieniają się e-mailami z kimś pochodzącym z innej kultury. Stąd może bardziej odpowiednią

5 Mechanizmy funkcjonowania megalomanii narodowej polegające na nacjonalizacji Boga i deifikacji narodu znakomicie opisał poznański etnolog i socjolog Jan S. Bystroń (1935) w klasycznej pracy Megalomania narodowa. 
nazwą byłoby określenie takiego rodzaju imperatywów mianem imperatywów interakcyjnych. „Wyzwanie polega na tym, żeby umysły i serca ukształtowane przez długie tysiąclecia życia w lokalnych gromadach wyposażyć w idee oraz instytucje, które pozwolą nam żyć razem, jako globalne plemię, którym się staliśmy" - zauważa Kwame A. Appiah (2008: 11).

\section{KSZTAŁCENIE W ZAKRESIE KOMPETENCJI MIĘDZYKULTUROWYCH NA PRZYKŁADZIE LUBELSKIM}

Relacje międzykulturowe w swej istocie są źródłem napięć, konfliktów, a w skrajnej postaci - nienawiści manifestowanej werbalnie, a nawet fizycznie. Dychotomiczne postrzeganie rzeczywistości, oparte na wydawałoby się uniwersalnych opozycjach my-oni, prowadzi do zamykania się w klatkach uprzedzeń i stereotypów. Wyjściem jest przede wszystkim kształcenie - promowanie kompetencji międzykulturowych, które mogą zapobiegać ukrytej i jawnej agresji na tle różnic kulturowych.

Skutecznie postawy dialogiczne na poziomie uniwersyteckim można rozwijać w dwóch zasadniczych obszarach edukacyjnych: formalnym (tworzenie programów kształcenia dostarczających wiedzy, umiejętności i kompetencji społecznych w zakresie wielokulturowości) oraz humanistycznym, interakcyjnym. Oba aspekty zostaną omówione na przykładzie innowacyjnego kierunku studiów anglojęzycznych drugiego stopnia, prowadzonego od dwóch lat na Wydziale Humanistycznym Uniwersytetu Marii Curie-Skłodowskiej w Lublinie pn. Intercultural Communication in Education and the Workplace.

Program, współfinansowany pierwotnie ze środków unijnych, skierowany jest do studentów z zagranicy zainteresowanych studiami drugiego stopnia w języku angielskim, a także do studentów polskich pragnących studiować w języku angielskim w środowisku międzynarodowym. Stanowi on efekt wieloletnich doświadczeń kulturoznawców, antropologów kultury i językoznawców związanych z UMCS (z Instytutu Nauk o Kulturze oraz z Instytutu Neofilologii).

Program kształcenia na tym kierunku oparty jest na czterech zasadniczych blokach tematycznych, pozwalających na zdobycie kompetencji międzykulturowych i umiejętności niezbędnych do funkcjonowania w środowisku międzykulturowym. Blok pierwszy - kulturoznawczy - zawiera przedmioty dotyczące komunikacji międzykulturowej, antropologii kulturowej i historii kultury, psychologii kontaktów międzykulturowych, kompetencji międzykulturowych, funkcjonowania mniejszości narodowych i etnicznych w wielokulturowym świecie, a także mediów jako nośnika wielokulturowych treści. W tym bloku tematycznym stawia się jednocześnie na praktykę, proponując warsztaty umiejętności 
międzykulturowych oraz moduł dotyczący kompetencji „miękkich”, tj. komunikacji niewerbalnej w ujęciu międzykulturowym.

Blok drugi dotyczy znaczenia języka w kulturze i obejmuje przedmioty traktujące o wieloaspektowości relacji języka i kultury. Omawiane są tu główne obszary, w których język i kultura spotykają się i wywierają na siebie wpływ. Celem jest wyposażenie studentów w wiedzę dotyczącą takich zagadnień, jak języki w Europie i na świecie czy wielojęzyczność w życiu codziennym.

Blok trzeci to praktyczna nauka języków obcych, czyli doskonalenie kompetencji językowej (wymowa, gramatyka, słownictwo) w zakresie języka angielskiego (do zakładanego poziomu B2+ lub C1 na zakończenie studiów). Oprócz tego blok ten obejmuje doskonalenie kompetencji w zakresie drugiego języka obcego.

Blok czwarty natomiast odnosi się do procesu tworzenia prac magisterskich o profilu kulturoznawczym lub lingwistycznym. W obu wypadkach celem pracy jest zaobserwowanie, opisanie i wyjaśnienie ludzkich zachowań (w tym językowych) w warunkach wielokulturowości i wielojęzyczności lub w kontaktach międzykulturowych. Chodzi o wykorzystanie wiedzy na temat wielokulturowości i umiejętności językowych na konkretnym materiale badawczym.

Program studiów ma na celu połączenie wiedzy dotyczącej kulturowego i lingwistycznego zróżnicowania świata z praktycznymi umiejętnościami językowymi, umożliwiającymi swobodne poruszanie się w środowiskach międzykulturowych. Niezwykle ważnym aspektem tego programu jest wyrobienie tzw. myślenia antropologicznego, opartego na refleksyjnej i krytycznej analizie zjawisk kulturowych w duchu relatywizmu kulturowego, holizmu i komparatywizmu. Zakłada się cele praktyczne, np. takie, że student jest w stanie opracować i rozpowszechniać projekty propagujące tego typu postawy (i tak właśnie się dzieje), co jest szczególnie ważne w kontekście coraz częściej pojawiających się aktów przemocy ze względu na rasę, narodowość czy pochodzenie etniczne.

Osiągnięcie efektów uczenia się związane jest ze stosowanymi metodami dydaktycznymi, mieszczącymi się raczej w kategorii problem solving method niż banking method (Darder 2015, 2017). Staramy się odtechnicyzować edukację, kładąc nacisk na refleksyjność, autoironię i krytyczne myślenie - „słowem to wszystko, co pozwala używać przekonań, a nie je tylko mieć" (Kusio 2011: 272). Wychodzimy z założenia, że edukacja nie może trywializować ani marginalizować różnic, „może nawet powinna zacząć od mnożenia problemów i trudności, by uzmysłowić jednostkom, jak ciężka praca je czeka w pokonywaniu drogi do Innego. Rozpoznanie, a nie ufne bagatelizowanie trudności powinno zbliżać do celu" (tamże: 274).

Drugi ważny cel przyświecający programowi studiów to bezpośrednie interakcje studentów funkcjonujących w przemieszanych kulturowo grupach. 
Integracja odbywa się w ramach spotkań zarówno studentów z tego samego kierunku, jak i z polskimi studentami przy okazji wydarzeń kulturalnych (Dzień Kulturoznawcy, spotkania świąteczne). Integracja taka rzeczywiście się dokonuje. Stajemy tu „przed koniecznością postrzegania i rozumienia nie tyle wielości, ile interakcji kultur pojętej jako coś więcej niż system ich wzajemnych re-Akcji - czyli pasywnych działań dostosowawczych, a więc właśnie inter-Akcji" (Korporowicz 1997: 69). Przed takim wyzwaniem praktycznym stają studenci pochodzący z takich krajów, jak m.in. Chiny, Indie, Irak, Zimbabwe, Nigeria, Gruzja, Rumunia, Rosja, Ukraina i Polska.

Połączenie edukacji formalnej z doświadczeniem jednostki odbywającym się „tu i teraz" daje szansę na skuteczne nabycie kompetencji międzykulturowych, a postawy z nich wynikające stanowią ważny oręż $\mathrm{w}$ walce $\mathrm{z}$ uprzedzeniami na tle kulturowym i religijnym. Stopień kompetencji międzykulturowej zależy zatem, ponownie przywołując koncepcję Deardorff, od nabytych postaw, wiedzy/ zrozumienia i umiejętności.

Tworzenie programów kształcenia na poziomie uniwersyteckim w zakresie wielokulturowości odbywa się w Polsce - z różnym skutkiem - od wielu lat. Opisany powyżej program kształcenia jest jedną z propozycji, która wdraża w życie założenia dotyczące kształcenia międzykulturowego w zakresie oferowania konkretnej wiedzy, umiejętności praktycznych i kompetencji społecznych. Wydaje się jednak, że edukacja w tym zakresie powinna być prowadzona na dużo wcześniejszym etapie, aby mogła zakończyć się powodzeniem, tj. skutecznym nabyciem kompetencji międzykulturowych. Z pewnością celowe byłoby wprowadzenie do szkół średnich obligatoryjnych zajęć dotyczących wielokulturowości oraz wiedzy o religiach i związkach wyznaniowych. Wiedza ta powinna być poszerzana w ramach kształcenia w zakresie wielokulturowości na wszystkich kierunkach studiów humanistycznych i społecznych.

\section{ZAKOŃCZENIE}

W wywiadzie udzielonym Tomaszowi Skoremu z Radia RMF FM John Godson - trzeci w historii polski parlamentarzysta-imigrant, a zarazem duchowny, który pochodzi z Nigerii - powiedział, że Polacy nie są przychylni obcym. Pytany dalej, czy są rasistami, odpowiedział „dyplomatycznie”, że nie są ani rasistami, ani ksenofobami, ale posiadają niskie kompetencje międzykulturowe. Sytuacja taka, jego zdaniem, jest efektem braku kontaktu z ludźmi pochodzącymi z innych kultur (Godson 2015), czyli homogeniczności polskiej kultury. Wiele lat wcześniej Krzysztof Wielecki, opisując przeszkody w integracji Polski z Unią Europejską, wymienił kłopoty Polaków z tolerancją dla odmienności 
kulturowej i uznał za warunek sine qua non działanie na rzecz rozwoju dyspozycji, którą określił jako kompetencję do komunikacji międzykulturowej (Wielecki 1995: 115-121). Warto w tym miejscu odwołać się także do konstatacji Barbary Olszewskiej-Dyoniziak (1998: 10), według której „[s] kuteczne komunikowanie zależy [...] od wiedzy i edukacji na temat »odmienności«. Pozwala przełamywać bariery negatywnych stereotypów, kształtować postawy otwarte i liberalne wobec odmienności”. Takie są właśnie podstawowe cele kształtowania kompetencji międzykulturowych. Z kolei według Leszka Korporowicza:

[...] w przypadku dużych różnic efekty komunikacji zależeć będą od zdolności zyskania dystansu do własnej kulturowej „przedmiotowości”, od zdolności transcendowania ku czemuś, co zaledwie jest przeczuwalne lub wyobrażone. Dlatego komunikacja międzykulturowa jest tyleż praktyką, ile wyzwaniem, testem naszej wrażliwości i twórczości, projekcją potrzeb i postaw. (Korporowicz 1995: 40; zob. także: Morawska 2009: 93-102)

Warto docenić podejmowane wysiłki na rzecz praktyki - promowania kompetencji międzykulturowych w szkołach, na uczelniach, czego egzemplifikacją jest właśnie propozycja opisanego w niniejszym artykule kierunku studiów anglojęzycznych. Zarówno taka wiedza, jak i postawy i umiejętności stanowią istotną wartość, która przekłada się na jakość interakcji międzykulturowych.

\section{BIBLIOGRAFIA}

Appiah, K.A. (2008). Kosmopolityzm: etyka w świecie obcych. Warszawa: Prószyński i S-ka.

Bauman, Z. (2016). Obcy u naszych drzwi. Warszawa: Wydawnictwo Naukowe PWN. Bem, M. (2013). Modele kompetencji międzykulturowych. W: J. Muszyńska, W. Danilewicz,

T. Bajkowski (red.), Kompetencje międzykulturowe jako kapitał społeczności wielokulturowych (s. 119-136). Warszawa: Wydawnictwo Akademickie „Żak”.

Berg, M.V., Paige, R.M. (2009). Applying Theory and Research: The Evolution of Intercultural Competence in the U.S. Study Abroad. W: D.K. Deardorff (ed.), The SAGE Handbook of Intercultural Competence (s. 419-437). Thousand Oaks: Sage Publications, Inc.

Bok, D. (2009). Foreword. W: D.K. Deardorff (ed.), The SAGE Handbook of Intercultural Competence (s. 9-10). Thousand Oaks: Sage Publications, Inc.

Bolten, J. (2006). Interkulturowa kompetencja. Poznań: Wydawnictwo Naukowe UAM. Bystroń, J.S. (1935). Megalomania narodowa. Warszawa: Towarzystwo Wydawnicze Rój. Chutnik, M. (2007). Szok kulturowy - przyczyny, konsekwencje, przeciwdziatanie. Kraków: TAiWPN Universitas.

Darder, A. (2015). Freire and Education. New York: Routledge. 
Darder, A. (2017). Reinventing Paulo Freire: A Pedagogy of Love. New York - London: Routledge.

Deardorff, D.K. (2011). Assessing Intercultural Competence. New Directions for Institutional Research, no. 149, 65-79, DOI: https://orcid.org/10.1002/ir.381.

Deardorff, D.K. (ed.). (2009). The SAGE Handbook of Intercultural Competence. Thousand Oaks: Sage Publications, Inc.

Deardorff, D.K., Arasaratnam-Smith, L.A. (eds.). (2017). Intercultural Competence in Higher Education International Approaches, Assessment and Application. London: Routledge.

Godson, J. (2015). Na pierwszy rzut oka Polacy nie sa przychylni. Musimy wykorzystać polska gościnność. Pobrane z: www.rmf24.pl/tylko-w-rmf24/danie-do-myslenia/news-john-godson-na-pierwszy-rzut-oka-polacy-nie-sa-przychylni-mu,nId,1890775 [dostęp: 28.12.2019].

Grzybowski, P.P. (2008). Edukacja międzykulturowa - przewodnik. Pojęcia - literatura - adresy. Kraków: Oficyna Wydawnicza Impuls.

Gudykunst, W.B., Kim, Y.Y. (2008). Komunikowanie się z obcymi: spojrzenie na komunikację międzykulturową. W: J. Stewart (red.), Mosty zamiast murów. Podręcznik komunikacji interpersonalnej (s. 496-511). Warszawa: Wydawnictwo Naukowe PWN.

Hasło: Kompetencja. Pobrane z: https://sjp.pwn.pl/sjp/kompetencja;2564077 [dostęp: 14.12.2019].

Hofstede, G.J. (2009). The Moral Circle in Intercultural Competence Trust Across Cultures. W: D.K. Deardorff (ed.), The SAGE Handbook of Intercultural Competence (s. 85-99). Thousand Oaks: Sage Publications, Inc.

Kapuściński, R. (2007). Spotkanie z Innym jako wyzwanie XXI wieku. Kraków: TAiWPN Universitas.

King, P.M., Baxter Magolda, M. (2005). A developmental model of intercultural maturity. Journal of College Student Development, vol. 46(6), 571-592, DOI: https://doi. org/10.1353/csd.2005.0060.

Kluckhohn, C. (2018). Mirror for Man. New York: Routledge.

Korporowicz, L. (1995). Od konfliktu do spotkania kultur, czyli tożsamość jako reguła autotransformacji. W: A. Kapciak, L. Korporowicz, A. Tyszka (red.), Komunikacja międzykulturowa. Zbliżenia i impresje (s. 31-40). Warszawa: Instytut Kultury.

Korporowicz, L. (1997). Wielokulturowość a międzykulturowość: od reakcji do interakcji. W: M. Kempny, A. Kapciak, S. Łodziński (red.), U progu wielokulturowości. Nowe oblicza społeczeństwa polskiego (s. 64-72). Warszawa: Oficyna Naukowa.

Kusio, U. (2011). Dialog w komunikacji międzykulturowej. Ideały a rzeczywistość. Lublin: Wydawnictwo UMCS.

Lewowicki, T., Ogrodzka-Mazur, E., Szczurek-Boruta, A. (red.). (2000). Edukacja międzykulturowa w Polsce i na świecie. Katowice: Wydawnictwo Uniwersytetu Śląskiego.

Lewowicki, T., Różańska, A., Klajmon-Lech, U. (red.). (2012). Religia i edukacja międzykulturowa. Toruń: Wydawnictwo Adam Marszałek.

Lustig, M.W., Koester, J. (2010). Intercultural Competence: Interpersonal Communication Across Cultures. Boston: Pearson Education, Inc. 
Majchrzak, N., Zduniak, A. (red.). (2013). Edukacja międzykulturowa w warunkach kultury globalnej. Od rozważań definicyjnych do praktycznych zastosowań. Poznań: Wydawnictwo Wyższej Szkoły Bezpieczeństwa.

Mauro, M. di (2015). The extension of intercultural competence today: From individual effectiveness to innovative, responsible and sustainable practices. W: E.J. Nash (ed.), Intercultural Horizons. Vol. 3: Intercultural Competence Key to the New Multicultural Societies of the Globalized World (s. 281-296). Cambridge: Cambridge Scholars Publishing.

Morawska, I. (2009). Dialog kultur jako wyzwanie edukacyjne. W: B. Myrdzik, M. Karwatowska (red.), Dialog kultur w edukacji (s. 93-102). Lublin: Wydawnictwo UMCS.

Myrdzik, B., Karwatowska, M. (red.). (2009). Dialog kultur w edukacji. Lublin: Wydawnictwo UMCS.

Nikitorowicz, J. (1995). Pogranicze. Tożsamość. Edukacja międzykulturowa. Białystok: Trans Humana.

Olszewska-Dyoniziak, B. (1998). Oblicza kultury. Wstęp do antropologii międzykulturowej komunikacji. Kraków: Wydawnictwo UJ.

Osiecki, G., Grajewski, Ł. (2019). Imigracja idzie na rekord. Liczba cudzoziemców pracujących w Polsce wciąż się powiększa. Pobrane z: https://serwisy.gazetaprawna.pl/ praca-i-kariera/artykuly/1424408,cudzoziemcy-pracujacy-w-polsce.html [dostęp: 28.12.2019].

Skałecka, K. (2010). O Uniwersytecie. Podstawowe informacje. Pobrane z: https://www. umcs.pl/pl/podstawowe-informacje,65.htm [dostęp: 28.12.2019].

Spitzberg, B.H., Changnon, G. (2009). Conceptualizing Intercultural Competence. W: D.K. Deardorff (ed.), The SAGE Handbook of Intercultural Competence (s. 2-52). Thousand Oaks: Sage Publications, Inc.

Trimble, J.E., Pedersen, P.B., Rodela, E.S. (2009). The Real Cost of Intercultural Incompetence. An Epilogue. W: D.K. Deardorff (ed.), The SAGE Handbook of Intercultural Competence (s. 492-503). Thousand Oaks: Sage Publications, Inc.

Wielecki, K. (1995). Kompetencje do komunikacji międzykulturowej: problemy polityczne i edukacyjne. W: A. Kapciak, L. Korporowicz, A. Tyszka (red.), Komunikacja międzykulturowa. Zbliżenia i impresje (s. 115-121). Warszawa: Instytut Kultury. 